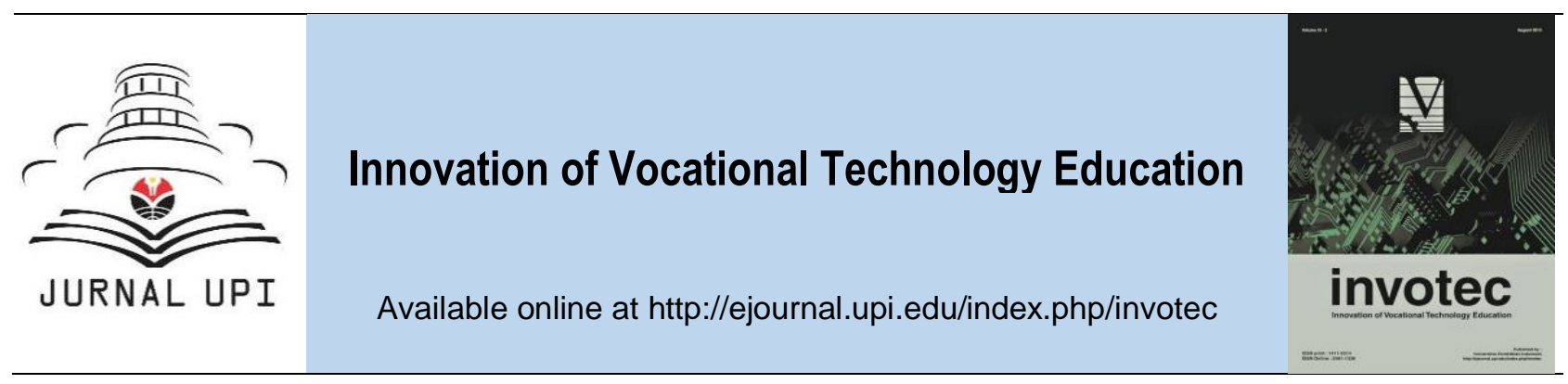

\title{
Relationship between Apprenticeship Training with Information and Communication Technologies at Vocational High School in West Java Province
}

\author{
A. Maulana and G. J. Jun \\ School of Education, Nanjing Normal University. Ninghai Lu No. 122, Nanjing Jiangsu Province 210000 \\ China
}

\section{ARTICLE INFO}

Article history:

Received: 21 May 2018

Received in revised form: 27 June

2018

Accepted: 22 July 2018

Available online: 31 August 2018

Keywords:

Apprenticeship Training,

$21^{\text {st }}$ Century skill,

Information and

Communication Technologies

Corresponding author:

amp_aflah@yahoo.com

\section{A B S T R A C T}

\section{Introduction}

Ministry of Education and Culture of Indonesia analyzes that changes in the labor market as one indicator of changes in employment. In the perspective of the education and training systems, the change pattern of employment is interpreted as the level of graduate hiring. This data also shows the pattern change pattern of employment is interpreted as the level of graduate hiring. This data also shows the pattern of graduate employment between vocational school (SMK) and senior high school (SMA).

The first period (5 years) from 2000 to 2005, the number of employed vocational school (SMK) graduates was higher than that of senior high school (SMA). However, in the third period 2010-2015, the level of working SMA graduates was more than SMK's. The substantial change in employment indicates a shift in the labor market as shown in the Figure 1 below: 


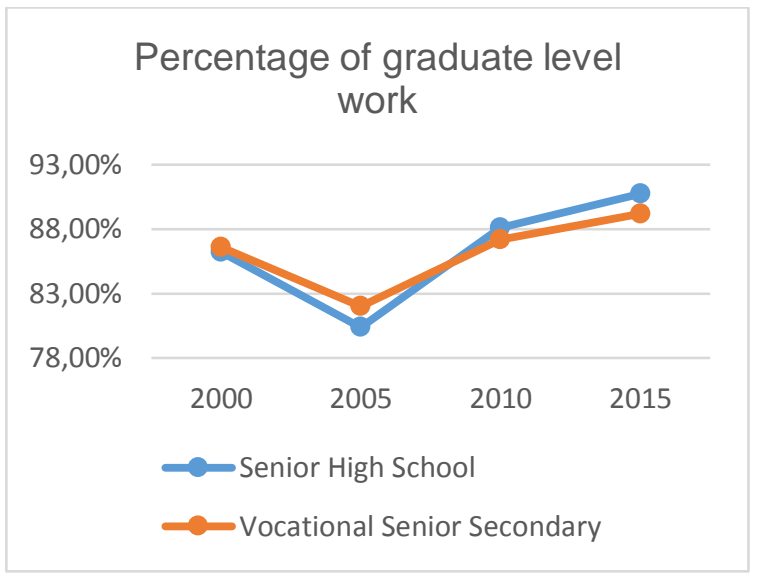

Figure 1. The dynamics of SMA (Senior High School) and SMK (Vocational School) (Source BPS, Sakernas 2000, 2005, 2010, 2015 Average February from August or November)

Three factors changes in work level of senior high school graduates to become higher than vocational high school graduates are:

1. Changes in job characteristics. It seems that various job opportunity requires a more general skill, that is logical thinking rather than just the skill of making products and services, as stated in the $21^{\text {st }}$ Century skills.

2. The increasing number of SMK creates an oversupply of graduates. The ratio of SMA and SMK from 2005 to 2015 has become 30:70.

3. New needs of workers who are able to think logically instead of manual skill (Team vokasi, 2016).

According to the $69^{\text {th }}$ and $70^{\text {th }}$ regulation issued by the Ministry of Education and Culture in 2013 about the basic framework and structure of the SMA/MA and SMK/MAK respectively, vocational students get more learning our per week compared to general school students. The longer learning hour for SMK is meant to give more instruction on skills. Furthermore, in vocational high school, students will have to take an apprenticeship program. The apprenticeship is intended to do learning by doing in the industry which specifically designed for vocational school students. This program is an integral part of the dual system education which the portfolio of the students in the industry will be one of the basis evaluation.

Looking at the gloomy side the data shows, which less SMK graduates finding their places in the job market, it is indicated that there is a problem in the vocational education system. The alumni of SMK fail to grab $21^{\text {st }}$ century skills.

\section{Implementation of Apprenticeship in Various Countries}

Vocational high schools (SMK) in Indonesia specifically train the students to have be skillful and ready to work. It is the utmost purpose of SMK. Students graduating from SMK are about 16-18 years old. Still young but their entering the world of work is a symbolic division between being a young and becoming an adult. So they must be given the opportunity to pursue vocational trainings or studies leading to professional qualification which also gives them softskill to become functional adult and professionals and to avoid having difficulty taking the critical step into the world of work or are denied the opportunity completely (Wieland, 2008). In that training period, the students must be able to assess their strengths and weaknesses before entering the work.

The job market now shows that the need for university degree and low-skill labor is is stagnant if not declining. On the other hands, middle-skill workers demand is on the rise. These skills are delivered by vocational training which typically available under the apprenticeship system. Students of vocational high school are guided through career education programs, work experience, field observation and mentored practices. In Indonesia setting, some of these programs are promoted and run by TVET program (Technical and Vocational Education and Training) or PPTK (Technical and Vocational Education and Training). They try to resemble Australia with its TVET program involving school-based training and apprenticeship. the program helps students develop habits and work attitudes and develop specific competencies during their study (McMahon and Patton, 2012). 
In general, it is important to elaborate the importance of apprenticeship to the students. In general, the apprenticeship has shown that it can minimize the age problem in youth willing to work. The appernticeship program make substansive difference eventhough the person work on different field from his/her apprenticship, as very often happens. In addition, now we know the term advanced apprenticeships. It is a non-age specific (Wolf, 2011). Australia government in middle of 1990 year have program of apprenticeship for all age among others graduate of school, part time job workers, and full time job workers. This program was very important to expand skills based company and provide safe employment opportunities for school graduates (Smith, 2008).

The issue of apprenticeship program not only about competences, another aspect is gender. in Australia and England majority of occupations for which need apprenticeships are dominated by males since more men do the apprenticeship (Gonon, 2011). It goes to the workforce in which more men get better job.

In Germany vocational education system, students who take apprenticeship will work with a specified mentor in from industries such as Bosch, Siemens, Mercedes-Benz, Deutsche Bank, the Ministry of Tourism or other local agencies and workplaces. Since a contract is signed between the school, the employer, and the student, the school does not need to find future employment for the students. Students must "market themselves" to an employer, thus maintaining a direct relationship between workplace preparation and the skills required. In this way, business and industry have an additional opportunity to monitor the level of student preparation from the schools (Kidwell and Thomas, 2012). By being able to market themselves, students can make choice of employment.

China as the biggest country in Asia has its own apprenticeship program system since 2010. The Government of China issues reforms and education policies for the medium and long term goals by increasing the cooperation of schools and companies in the TVET (Technical and Vocational Education and Training) system. Cooperation between schools and industries comprise:

1. Administrative or stimulating measures implemented by governments and organizations at all levels

2. Cooperation between vocational schools and enterprises with:

a. Dividing school years (xue nian fen duan)

b. Half-work-half-study/work-study rotation (gong xue jiao ti)

c. Flexible arrangement (tan xing an pai)

d. Training orders (ding dan pei yang)

e. Work-study bases within the enterprises

f. Sector-led (hang ye zhu dao)

g. Teaching factories (jiao xue gong chang)

h. Enterprises' program replacement (ke cheng zhi huan).

3. Vocatioal education group (zhi jiao ji tuan) (Zhao, 2011).

Implementation of apprenticeship in China made more flexible with the course continues to be pursued in cooperation between industry and school.

However that is not always the case, a case study in Hungary has shown apprenticeship training cannot compensate for the poor quality of the vocational training school in Hungary. Neither apprentices nor non-apprentices find jobs right after graduation, and there is no significant difference in employment opportunities between the apprentice and non-apprentice during the year after graduation. Analyses of subsamples of the population, however, indicate that firms might utilize apprenticeship training to screen the best students (Horn, 2015). The opposition of apprenticeship argues that apprentices are only exploited rather than provided with quality training. Apprenticeship is very effective for employment opportunities because there are some students who undertake apprenticeship are selected before.

\section{Apprenticeship Program in Indonesia}

Indonesia has program of apprenticeship for vocational high school based on of Minister Education regulation number 60 at 2014 about the basic framework and structure of curriculum, especially for apprenticeship, as follows:

1. Apprenticeship can be implemented using a block system for half a semester (about 3 months); can also entry 3 days a week, every day 8 hours for 1 semester.

2. The $A$ and $B$ subject matter (normative and adaptive) can be learned during apprenticeship with portfolio as the main instrument of assessment.

3. Vocational high school arrange dual system program with industry or business sector. 
Which systematically integrates educational programs in schools with skills obtained through working directly in partner institutions towards to achieving a certain level of professional expertise. Apprenticeship in vocational high chool (SMK) is of implementation as syllabus of learning in industry. Implementation of this practice intended that students can actually use skills to nurture his confidence. Implementation of apprenticeship generally use learning block system adapted with sector industry (Hendarman, 2016). Implementation of apprenticeship in vocational high school for 3 years and 4 years as Table 1, follows:

Table 1. Implementation of dual system apprenticeship in vocational high school

\begin{tabular}{|c|c|c|c|c|}
\hline \multicolumn{3}{|c|}{3 years of program } & \multicolumn{2}{|c|}{4 years of program } \\
\hline 10 grade & Vocational skills & ractice in school & Vocational skills & actice in school \\
\hline 11 grade & $\begin{array}{l}\text { Work } \\
\text { competence } \\
\text { practise in } \\
\text { school }\end{array}$ & $\begin{array}{l}\text { Product realization } \\
\text { practise at } \\
\text { Teaching Factory } \\
\text { in school }\end{array}$ & Work competen & practise in school \\
\hline 12 grade & $\begin{array}{l}\text { Apprenticeship } \\
\text { in industry }\end{array}$ & $\begin{array}{l}\text { Career transition } \\
\text { for National Exam } \\
\text { and sertification }\end{array}$ & $\begin{array}{l}\text { Apprenticeship } \\
\text { in industry }\end{array}$ & $\begin{array}{l}\text { Product realization } \\
\text { practise at Teaching } \\
\text { Factory in school }\end{array}$ \\
\hline 13 grade & & & $\begin{array}{l}\text { Apprenticeship } \\
\text { in industry }\end{array}$ & $\begin{array}{l}\text { Career transition for } \\
\text { National Exam and } \\
\text { sertification }\end{array}$ \\
\hline Month & 3 & 12 & 3 & 9 \\
\hline
\end{tabular}

Apprenticeship program in Indonesia has character of Education and Culture based on Mutual cooperation. The function of industry sector are a place of practice, apprenticeship, learning industry and management for students. Other than to addition to student knowledge about world of work, collaboration between School and industry sector is based on willingness and mutual need. The industry sector need to find a good workers. Government, industry sector and school together compile Indonesian Qualifications Framework (KKNI) and to increase quality for students in apprenticeship program. On the other hand, apprenticeship program in Indonesia has limitations in equipment and materials which in return create constraints to improve the skills of vocational students. Schools have made efforts to improve the skills of students with a variety of co-operations with industry and companies. Students have to do an internship in a company. But due to various constraints the internship implementation does not run according to expectations (Wayan, 2012). Unfortunately, apprenticeship is not usually ready or fit for work as required by companies. Reorganize appreticeship with longer time for students to study in industry and business is one way to increase link and match between school and industry.

The apprenticeship system in Indonesia seek to meet labour market demands with graduate students by establishing a Skills Development Fund (SDF). Furthermore to create forum in Apprenticeship Communication Forum (FKJP Forum Komunikasi Jejaring Pemagangan). ILO (International Labour Organization) noted in Indonesia "At present, the national apprenticeship system is not coordinated by a single policy. Indonesian ministries run apprenticeship and training programmes independently, refusing to recognise the legitimacy of each other's' certification. Their programmes are industry-specific. Efforts at sector planning have been underway for a number of years, but the national policy on apprenticeship has not yet emerged as one unified umbrella" (TNP2K, 2015). Other than, national training system is not sufficient in fulfilling apprenticeship program in Indonesia without involving private sectors.

Finally apprenticeship is defined as learning by vocational students conducted outside the school aim to have skill (competence) to prepare to work through assess self-potential with school and industry support accomplished standard competence of work, with factors as follows: Working observations, work experience, work accompaniment, strength of self, weakness of self, job opportunities, good development of habits and competencies/specific skills.

\section{Globalization of Information and Communication Technologies (ICT)}

The rapid technological advancement and profound changes in many aspects of human activities in this era is often referred to as indicative of the world moving into the knowledge age. Such changes have stimulated much discussion about the role and processes of education as well as the role of ICT in teaching and learning in the new era. Information and Communication 
Technologies in several countries this goal had been achieved in only a small number of schools. Across countries, a majority of the technology coordinators said they were adequately prepared with regard to general applications in microsoft office (MS word, MS Excel, and MS power point) (Pelgrum and Law, 2008). On the other hand, utilization of email, social media and television is increangsing. ICT have impacted on all sectors of education by providing the means for ease of one to one and group communication while providing access to digital resource sharing (Stacey and Gerbic, 2006). For distance education through ICT is media of solutions are required with a sufficient internet network, can minimize face to face between the far distance. On the other hand, current time ICT media can be used video conferencing with teachers and students have the computer or laptop with good network quality.

The ICT is used in Switzerland through the MoKEx (Mobile Knowledge Experience) program, The MoKEx is collaboration field of education with industry (Hinkelmann, et. al., 2006). The MoKEx program adds to increase student competence as well as interdisciplinary knowledge exchange through ICT (computer science). students gain more an understanding by project management, communication competencies, data documentation, environmentally friendly ICT usage and technical skills about more advanced mobile devices. On the other hand, learning ICT has not been successful for instance at the University of Cape Town (South Africa). Research shows on line course by learning and experience through middle-level ICT contact (Ng'ambi, 2006). has factors influencing such as follows; on-line learning is not always dominating the learner's character. Students have been shaped by cultural differences, economic circumstances, student origins, and circumstances that differ in the quality of the Internet network for on-line learning in the context of ICT.

In the Czech Republic, the ministry of education include ICT in the education system, with the application of strategies as follows: Internet connections that reach schools and libraries, presenting coordinators of ICT in each school to assist students and teachers for learning and training, strengthening teacher training from information transmission of information methodology to problem solving in the context of ICT, introduction of programs for lifelong learning, introduction of programs for teachers and researchers in the use of ICT, and analysis and assessment of ICT policy (Lustigova, 2006). These strategies are intended for the effective use of ICT in the classroom.

In parts of Asia, especially China, they have made a decision in the modernization of education through ICT, the development of information and communication technology infrastructure, the application of digital resources, management and innovation in learning through ICT. Educational resources in the form of teaching and training sites are implemented with the motto "three connections and two platforms". The goals of ICT education in China for the 2020 are divided into medium and long-term development tasks. The purpose of this ICT education is to apply ICT in all aspects of education such as management, teaching, research, efficiency and quality of learning. The Chinese government focuses on the modernization of education in 2015, then entering the year 2016-2020 to continue the development of information ICT development in education (Wu, 2014). Chinanese government program of connecting schools with the Internet network has provided a quality device, especially given the size of the mainland China. This is a challenge that is not easy to solve. From several countries can be concluded that the ICT use with more developed in all countries, especially to face the $21^{\text {st }}$ century.

\section{Information and Communication Technologies (ICT) and $21^{\text {st }}$ Century Skills}

ICT is close related to policy and activities. As with the sphere of pedagogy, ICT is a major dimension of interest, primarily in terms of its interaction with pedagogy. The activities of pedagogy through information and communication technologies in summarized as follows: Student centered in learning, on-line learning, link schools with difference cultures, collaboration with others, communication and presentation teams through ICT. In addition to explicitly naming the trends associated with pedagogical reform, official references to goals or programs related to $21^{\text {st }}$-century skills implicitly recognize movement toward pedagogical reform. Policy statements on $21^{\text {st }}$-century skills consistently mention the need for active learning and student-centered learning, as well as the need for training in decision-making and collaborative work (Anderson and Plomp, 2008). The development of educational direction for student learning experiences in the classroom is toward to prepare learning in $21^{\text {st }}$ century skills for better education.

In 2008, Russia has done research for teachers' self-reported technical and pedagogical competence in ICT-use. Teachers were asked to indicate their self-perceived levels of competence 
in both general and pedagogical uses of ICT. The specific competences included in the survey for each of the two kinds of ICT-competence are as follows: Technical ICT competence: wordprocessing, email, taking and displaying digital photos filing electronic documents, using a spreadsheet, online discussion, producing an electronic presentation, online business transactions. Pedagogical ICT competence: Preparation of lessons where students use ICT, knowledge of pedagogical situations suitable for ICT-use, finding useful curriculum resources on the internet, using the internet to support student learning, using ICT to monitor students progress and evaluate students learning outcomes, using ICT to give effective presentations and using ICT to collaborate with others (Law and Chow, 2008). Technical ICT competence and pedagogical ICT competence must be fully mastered for the students in the face of competition in the $21^{\text {st }}$ century.

In education, the definition of information and communication technologies is tools to improve efficiency of learning. With government support and infrastructure, pedagogical ICT and technical ICT factors, both software and hardware, will reduce obstacles in distance and time in teaching in learning.

\section{Method}

The samples of this study are Grade 11 students in different vocational high school in West Java Province. The participating schools were purposely selected by the first Professional certification institution who conducted the field research. The Table 2 shows the demographics of the respondents and the participating schools.

Table 2. Sampling and Locale of the Study

\begin{tabular}{lllc}
\hline \multicolumn{1}{c}{ School } & \multicolumn{1}{c}{ City } & \multicolumn{1}{c}{ Field Competence } & Total \\
\hline The first vocational high school & Cibinong, Bogor district & $\begin{array}{l}\text { Information and communication } \\
\text { techniques }\end{array}$ & 79 \\
Vocational School Bhakti & Subang district & Health and social work & 75 \\
Kencana & & Agribusiness and agrotechnology & 66 \\
The first vocational high school & Pacet, Cianjur district & Business and management & 79 \\
The first vocational high school & Bandung City & Maritime & 73 \\
The first vocational high school & Mundu, Cirebon district & Information and communication & 81 \\
The first vocational high school & Garut district & techniques & 67 \\
The first vocational high school & Sukabumi city & Technology and engineering & 520 \\
\hline
\end{tabular}

This study is quantitative in nature and a survey method was utilized. The contents of the questionnaires were based from the apprenticeship connected with $21^{\text {st }}$ century skill information and communication technologies. The survey questionnaire follows a Likert scale (Table 3 ) with the following legend using positive or negative statement sentences, for apprenticeship variables $X$, information and communication technology literacy variables $\mathrm{Y}$.

\begin{tabular}{cc}
\multicolumn{2}{c}{ Table 3. Likert scale } \\
\hline Value & Response \\
\hline 1 & Strongly disagree \\
2 & Disagree \\
3 & Neutral \\
4 & Agree \\
5 & Strongly agree \\
\hline
\end{tabular}

The instrument used questionnaire to measure variabel of apprenticeship. The concept of the instrument has been tested with 57 people for apprenticeship variables consisting of 18 items, obtained 16 valid instruments. Calculation of validity for the instrument tested using Pearson product moment correlation and t test as Tabel 4, follows: 
invotec XIV:2 (2018) 55-66

Table 4. Grid of final instrument apprenticeship

\begin{tabular}{clccccc}
\hline \multirow{2}{*}{ No } & \multicolumn{1}{c}{ Indicator } & \multicolumn{2}{c}{ Number of Instrument } & \multicolumn{3}{c}{ Amount } \\
\cline { 3 - 7 } & & Positive & Negative & + & - & All \\
\hline 1 & Work observation, and work & & 7 & - & 1 & 1 \\
2 & $\begin{array}{l}\text { experience } \\
2\end{array}$ & $1,4,12$ & 15,16 & 3 & 2 & 5 \\
3 & $\begin{array}{l}\text { Sotivation to work strength, and self of } \\
\text { weakness }\end{array}$ & 2,14 & & 2 & - & 2 \\
4 & $\begin{array}{l}\text { Work opportunity } \\
\text { Development of good }\end{array}$ & 13 & 3,9 & 1 & 2 & 3 \\
5 & $\begin{array}{l}\text { habits and competencies or } \\
\text { specific skills } \\
\quad \text { Total }\end{array}$ & $5,8,10,11$ & 6 & 4 & 1 & 5 \\
\hline
\end{tabular}

To determine the reliability of the apprenticeship variable instrument using the formula "Alpha Cronbach". Based on the calculation obtained the reliability coefficient $r_{11}=0.791$ with $r_{\text {table }}=0.266$ product moment with $\mathrm{dk}=\mathrm{n}-1=57-1=565 \%$ significance level. The decision by comparing $\mathrm{r}_{11}=$ 0.791 with $r_{\text {table }}=0.266$, then $r_{11}>r_{\text {table, }}$, the appendix variable instrument means reliable.

The instrument used to measure information and communication technologies. is questionnaire. The instrument concept has been tested on 57 people for information and communication technologies variable consisting of 20 items, obtained 17 valid instruments. Calculation of validity for the instrument tested using Pearson product moment correlation and test as Table 5, follows:

Table 5. Grid of final instrument information and communication technologies

\begin{tabular}{ccccccc}
\hline \multirow{2}{*}{ No } & \multicolumn{1}{c}{ Indicator } & \multicolumn{2}{c}{ Number of instrument } & \multicolumn{2}{c}{ Amount } \\
\cline { 2 - 7 } & Positive & Negative & + & - & All \\
\hline 1 & $\begin{array}{l}\text { Information and } \\
\text { communication technology }\end{array}$ & $7,10,11,15$ & 5,14 & 4 & 2 & 6 \\
$\quad \begin{array}{l}\text { education } \\
\text { ICT techniques in software }\end{array}$ & $1,8,16$ & 3 & 3 & 1 & 4 \\
3 & $\begin{array}{l}\text { and hardware } \\
\text { Reduction time and distance } \\
4\end{array}$ & 2,9 & 12 & 2 & 1 & 3 \\
$\quad \begin{array}{l}\text { Learning using infromation } \\
\text { and communication } \\
\text { technology }\end{array}$ & $4,13,17$ & 6 & 3 & 1 & 4 \\
$\quad$ Total & & & 12 & 5 & 17 \\
\hline
\end{tabular}

To determine the reliability of variable instruments of information and communication technologies variable using the formula "Alpha Cronbach". Based on the calculation obtained the reliability coefficient $r_{11}=0.789$ with $r_{\text {table }}=0.266$ product moment with $\mathrm{dk}=\mathrm{n}-1=57-1=56$ significance level of $5 \%$. The decision by comparing $r_{11}=0.789$ with $r_{\text {table }}=0.266$, then $r_{11}>r_{\text {table }}$ then the instrument of information and communication technology variables means reliable.

\section{Result and Discussion}

The collected data were analyzed by statistical methods to test the research hypothesis in terms of knowing the strength of the relationship between apprenticeship with $21^{\text {st }}$ century skills information and communication technology. Data analysis was performed with statistical analysis techniques including descriptive statistics, analysis prerequisite tests, correlation research hypothesis testing and analysis of the coefficient of determination. The collected data is then processed use Microsoft Excel and SPSS version 20 to see the basic statistical calculations of the study consisting of mean, median, minimum value, maximum value, mode and class range. The results of the study for each variable obtained data and described. 


\section{Apprenticeship}

Description of research data on apprenticeship are presented in the Table 6 and 7 , as follows:

Table 6. Descriptive statistics of apprenticeship variable data use Microsoft Excel

\begin{tabular}{ccc}
\hline No & Criteria & Value \\
\hline 1 & Amount of sample & 520 \\
2 & Instrumen items & 16 \\
3 & Total & 31869 \\
4 & Highest score & 77 \\
5 & Lowest score & 41 \\
6 & Mean & 61.29 \\
7 & Median & 61 \\
8 & Mode & 60 \\
9 & Range & 36 \\
10 & Amount of class & 10 \\
11 & Class range & 3.6 \\
12 & Error rate & $95 \%$ \\
13 & Standard deviation & 5.0 \\
\hline
\end{tabular}

Table 7. apprenticeship variable data frequency distribution

\begin{tabular}{cccc}
\hline No & Interval class & Absolute frequency & Relative frequency (\%) \\
\hline 1 & $41-44$ & 1 & $0.2 \%$ \\
2 & $45-48$ & 5 & $1.0 \%$ \\
3 & $49-52$ & 6 & $1.2 \%$ \\
4 & $53-56$ & 61 & $11.7 \%$ \\
5 & $57-60$ & 171 & $32.9 \%$ \\
6 & $61-64$ & 147 & $28.3 \%$ \\
7 & $65-68$ & 84 & $16.2 \%$ \\
8 & $69-72$ & 42 & $8.1 \%$ \\
9 & $73-76$ & 2 & $0.4 \%$ \\
10 & $77-80$ & 1 & $0.2 \%$ \\
& Total & 520 & $100 \%$ \\
\hline
\end{tabular}

\section{ICT (information and communication technology)}

Description of research data information and communication technology (ICT) are presented in the Table 8 and 9, as follows:

Table 8. Descriptive statistics of ICT variable data using microsoft excel

\begin{tabular}{ccc}
\hline No & Criteria & Value \\
\hline 1 & Amount of sample & 520 \\
2 & Instruments item & 17 \\
3 & Total & 31226 \\
4 & Highest score & 73 \\
5 & Lowest score & 40 \\
6 & Mean & 60.05 \\
7 & Median & 60 \\
8 & Mode & 62 \\
9 & Range & 33 \\
10 & Amount of class & 11 \\
11 & Class range & 3 \\
12 & Error rate & $95 \%$ \\
13 & Standard deviation & 5.92 \\
\hline
\end{tabular}


Table 9. ICT variable data frequency distribution

\begin{tabular}{cccc}
\hline No & Class interval & Absolute frequency & Relative frequency (\%) \\
\hline 1 & $40-42$ & 5 & $1.0 \%$ \\
2 & $43-45$ & 6 & $1.2 \%$ \\
3 & $46-48$ & 8 & $1.5 \%$ \\
4 & $49-51$ & 22 & $4.2 \%$ \\
5 & $52-54$ & 37 & $7.1 \%$ \\
6 & $55-57$ & 74 & $14.2 \%$ \\
7 & $58-60$ & 121 & $23.3 \%$ \\
8 & $61-63$ & 114 & $21.9 \%$ \\
9 & $64-66$ & 61 & $11.7 \%$ \\
10 & $67-69$ & 41 & $7.9 \%$ \\
11 & $70-73$ & 31 & $6.0 \%$ \\
& Total & 520 & $100 \%$ \\
\hline
\end{tabular}

\section{Prerequisite Test Analysis}

Apprenticeship is independent variable and dependent variables is ICT (information communication technologies). Analysis requirements that must be done before to test hypotheses and regression analysis. Testing the variance homogeneity (Table 10) using the SPSS version 20 application, with the following test steps to the analyze menu $\rightarrow$ compare means $\rightarrow$ one-way ANOVA in the options selection select descriptive and homogeneity of variance test.

Table 10. Test of homogeneity of variances apprenticeship training

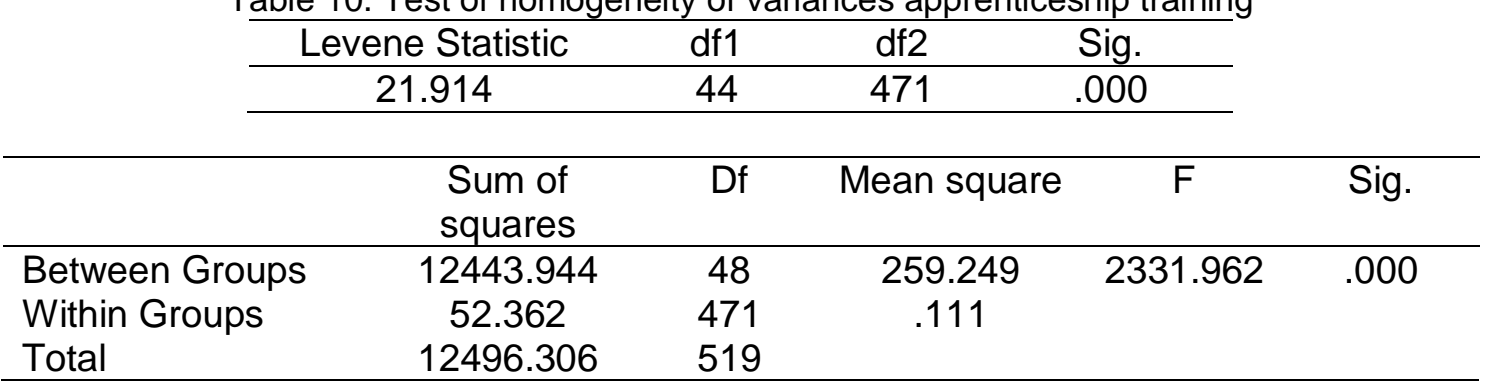

Analysis of the data homogeneity test will use the statistics of the Levene Statistic test, because the probability value of a column of Sig worth 0.000 means that the probability is $0.000<$ 0.05 , so the apprenticeship data has a different variance (not homogen). If the variance data is not homogen then non parametric statistical analysis is used.

Normality testing is done by testing the normality of the data with a plot with IBM SPSS version 20 , with the following steps analyze $\rightarrow$ descriptive statistics $\rightarrow$ explore then select normality plot with tests. The following results from the normality test (Figure 2 ) for each variable:

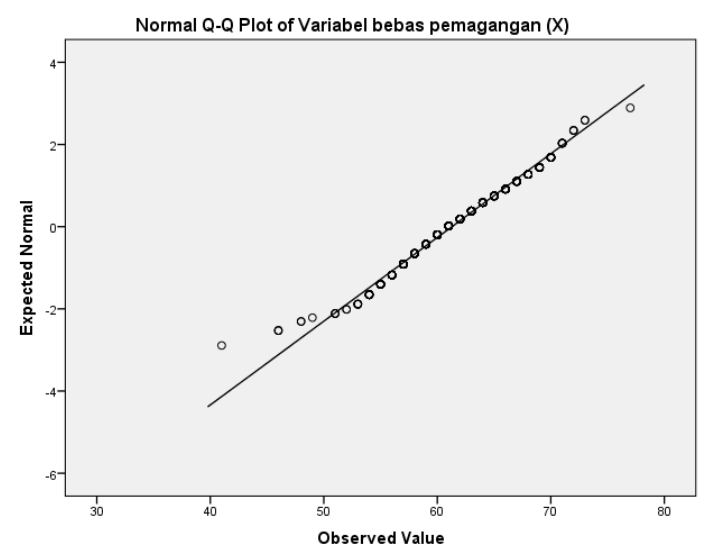

Figure 2. Test the data normality with the plot of apprenticeship training 
Data normality test (Table 11) analysis will be used Shapiro-Wilk test statistics, because the Sig value column is 0.000 meaning the probability is $0.000<0.05$, so the apprenticeship data is not normally distributed.

Table 11. Test of homogeneity of variances ICT

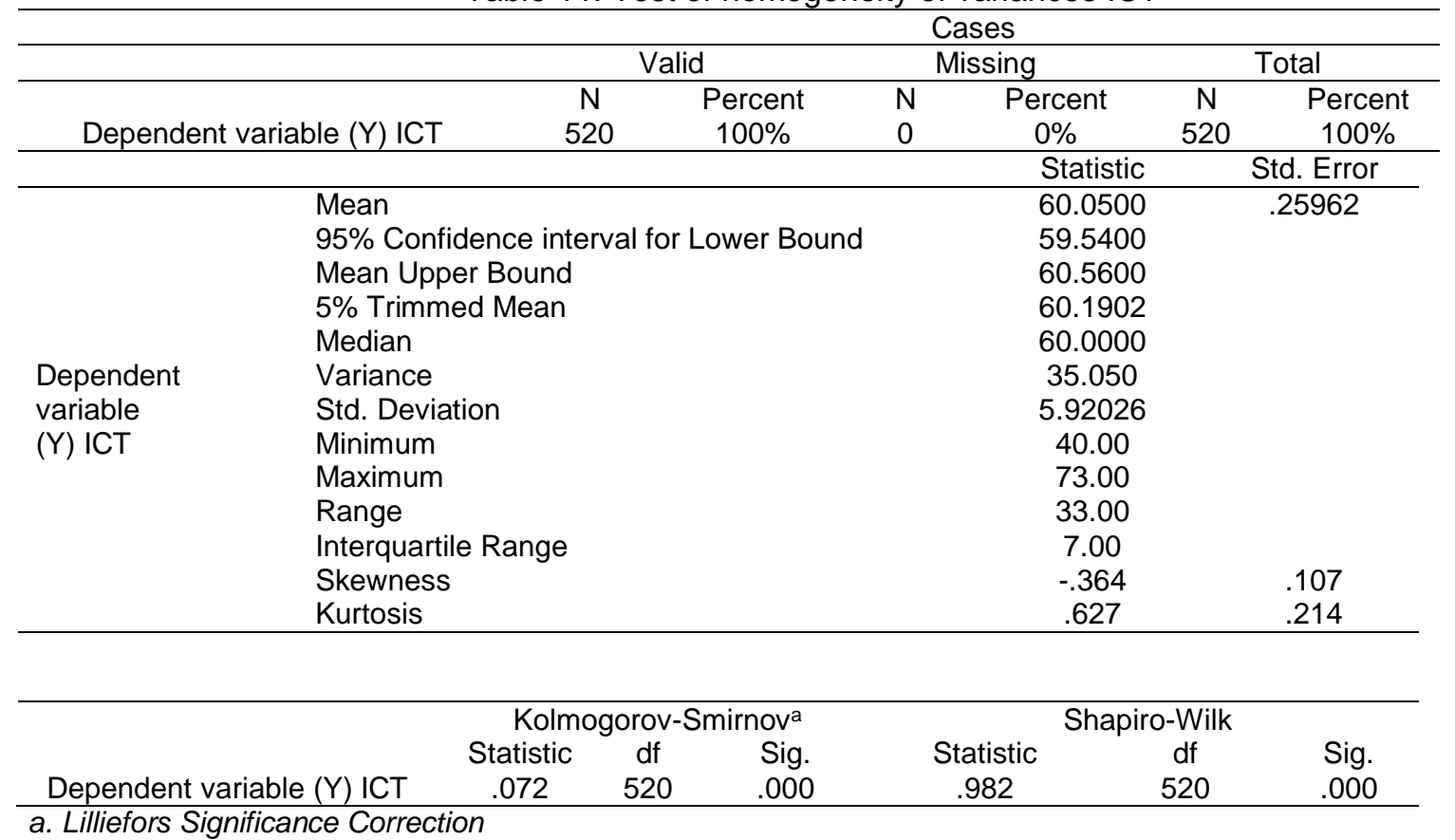

Data normality test (Table 12) analysis will be used Shapiro-Wilk test statistics, because the Sig value column is 0.000 meaning the probability is $0.000<0,05$ so the information and communication technology data is not normally distributed.

Table 12. Count of correlations between apprenticeship and ICT

\begin{tabular}{cclcc}
\hline & & & Apprenticeship & ICT \\
\hline & Independent & Correlation Coefficient & 1.000 & $.315^{\star *}$ \\
& variable (X) & Sig. (2-tailed) &. & .000 \\
Spearman's rho & apprenticeship & $\mathrm{N}$ & 520 & 520 \\
& Dependent & Correlation Coefficient & $.315^{\star *}$ & 1.000 \\
& variable (Y) ICT & Sig. (2-tailed) & .000 &. \\
& literacy & $\mathrm{N}$ & 520 & 520 \\
\hline${ }^{* *}$. Correlation is significant at the 0.01 level (2-tailed).
\end{tabular}

Look for $Z_{\text {count }}$ with $r_{s}=0.315$ and $n=520 . Z_{\text {count }}$ is 7.16 Look for $Z$ tables: with a confidence level of $99 \%$ and a significance level of $1 \%$ for 2 tailed tests. The area of the curve is $50 \%-0.5 \%=$ $49.5 \%$, from the $Z_{\text {table, }} Z_{\text {table }}$ is 2.58 . Because $Z_{\text {count }}=7.16>Z_{\text {table }}=2.58$ then $H_{0}$ is rejected meaning that there is have relationship between apprenticeship and ICT. By looking at the probability number, because in the Sig. (2-tailed) is $0.000<0.01$ then $\mathrm{H}_{0}$ is rejected. This means that there are have relationship between apprenticeship and ICT of vocational students.

\section{Conclusion}

The correlation coefficient then the coefficient of determination is calculated for the apprenticeship variable $(\mathrm{X})$ with ICT literacy variable $(\mathrm{Y})$, the value of the correlation coefficient rs is squared to get the coefficient of determination $\left(r_{y}\right)^{2}=(0.315)^{2}=0.0992$, this shows the apprenticeship contributes $9.92 \%$ of the ICT of vocational students in West Java, while $90.08 \%$ were influenced by other factors.

The relationship between apprenticeship and information and communication technology conducted of the research is below 10 percent, but in generaly using of information technology is very necessary. Can be said apprenticeship as a learning for vocational high school students conducted inside or outside of school aims to achieve the competencies needed to prepare 
themselves in the workforce through evaluating their ability with schools and industrial sectors to achieve work competency standards. With the following factors: work observation, work experience, job coaching, self strengths, self weaknesses, job opportunities, good habits development and achievement of specific competencies.

Apprenticeship as a form of learning for vocational students is expected to be a valuable learning experience to improve their ability to prepare for work. Working in the current era requires $21^{\text {st }}$ century skills and abilities (soft skills) in information and communication technology literacy. A vocational student will have ICT skill by following apprenticeship and discipline well. Efforts to improve ICT literacy through apprenticeship in education is a tool to improve learning efficiency through video conferences, e-mail, on line discussions and paper less. Procurement of ICT, especially in the implementation of apprenticeship, must have support from the industrial world or the business world where the internship is carried out. In fact, in the business world or the industrial world, the use of ICT can be more or less compared to vocational schools where students are studying internships. However, the existence of ICT in the internship place will greatly help information and communication technology literacy for vocational students who carry out apprenticeship.

\section{References}

Anderson, R. E., and Plomp, T. (2008). National Contexts. Comparative Education Research Centre.

Gonon. (2011). Distinctiveness and Diversity Within Vocational Education. Science+Business Media. Australia.

Hendarman. (2016). Revitalisasi Pendidikan Vokasi. Jakarta: Kementerian Pendidikan dan Kebudayaan Republik Indonesia.

Hinkelmann, K. et. al, (2006). Linking Communities of Practice with Learning Communities in Computer Science Education. Education for the 21" Century-Impact of ICT and Digital Resources. Switzerland.

Horn, D. (2015). The effectiveness of apprenticeship training: $A$ within-track comparison of workplace-based and school-based vocational training in Hungary. Hungary.

Kidwell, F. L., and Thomas, M. (2012). Lessons from Germany and the Future of Vocational Educatio. West Germany.

Lustigova, Z. (2006). Role of Online Supportive Environment in Professional Development of Inservice Teachers-Case of TELMAE. Education for the 21" Century-Impact of ICT and Digital Resources. Czech Republic.

McMahon, M. and Patton, W. (2012). Technical and Vocational Education and Training in the $21^{\text {st }}$, Building Positive Work Habits and Attitudes. France: UNESCO.

Ng'ambi, D. (2006). Influence of Individual Learning Styles in Online Interaction: a Case for Dynamic Frequently Asked Questions (DFAQ). Education for the 21 Century-Impact of ICT and Digital Resources. South Africa.

Smith, E. (2008). The crowded market: Agencies dealing with apprenticeships in Australia. School of Education. NSW Australia: Charles Sturt University.

Stacey, E. and Gerbic, P. (2006). Teaching for Blended Learning How is ICT impacting on distance and on campus education? Education for the 21" Century-Impact of ICT and Digital Resources. New Zealand. 
Tim Nasional Percepatan Penanggulangan Kemiskinan (TNP2K). (2015). Supply of Non-formal training in Indonesia. Working paper. Jakarta.

Wayan, I. (2012). Enhancing the Image and Attractiveness of TVET. Proceedings of the 2nd UPI International Conference on Technical and Vocational Education and Training. Bandung, Indonesia.

Wieland, C. (2008). Situated Competence Development through Innovative Apprenticeships The Role of Different Stakeholders. Bertelsmann Foundation. Preface Conference Proceedings, International Network on Innovative Apprenticeship (INAP). Vienna, Austria.

Wolf, A. (2011). Review of Vocational Education. Britain: The Wolf Report.

Wu, D. (2014). An Introduction to ICT in Education in China, ICT in Education in Global Context. Verlag Berlin: Heidelberg.

Zhao, Z. (2011). School-enterprise cooperation in China's vocational education and training. Institute of Vocational and Adult Education. Beijing: Beijing Normal University. 